\title{
QUALITY OF BOTTOM SEDIMENTS OF MIDFIELD PONDS AND THEIR EVALUATION FOR THE POTENTIAL THREAT OF THE AQUATIC ENVIRONMENT
}

\author{
Kamil Szydłowski ${ }^{1}$ Adam Brysiewicz², Piotr Wesołowski², Joanna Podlasińska' \\ 1 Department of Ecology, Environmental Management and Protection, The West Pomeranian University of \\ Technology in Szczecin, Poland, e-mail: kamil.szydlowski@zut.edu.pl \\ 2 West Pomeranian Research Centre, Institute of Technology and Life Sciences, Szczecin, Poland
}

Received: 2016.09.14

Accepted: 2016.10.23

Published: 2017.01.01

\begin{abstract}
The study aimed at the evaluation of the quality of bottom sediments and evaluation of potential threat to the aquatic environment. Cadmium, cobalt, chromium, copper, nickel, lead, zinc and mercury concentration in the separate layers of the sediments in the pond at Żelisławiec decreased with the depth of bottom sediments. On the other hand, the highest concentrations of the studied elements occurred in the deepest layer of sediments in the pond at Stare Czarnowo. The level of the potential ecological risk (PER) for the sediments of the Żelisławiec pond classifies them as sediments with low quality of the potential ecological risk, whereas the sediments from the pond at Stare Czarnowo are classified as moderate level of the potential ecological risk. In both ponds, the highest $\mathrm{I}_{\text {geo }}$ values were reported for zinc and lead.
\end{abstract}

Keywords: midfield ponds, sediments, surface water, heavy metals

\section{INTRODUCTION}

Bottom sediments constitute an integral part of the aquatic environment. They are the location of accumulation and chemical transformations of numerous compounds that penetrate to waters. The majority of heavy metals with low solubility and hardly degradable are introduced to the environment as a result of human activity and penetrates to surface waters, where they are accumulated in sediments. Thus, sediments contaminated with trace metals constitute a serious threat to the biosphere. Part of the harmful substances contained in aquatic sediments can be transferred to water as a result of chemical and biochemical processes and become available to living organisms [Baran and Tarnawski 2013; Bojakowska 2001; Szydłowski and Podlasińska 2016b]. Trace metals present in water are very rapidly cumulated in bottom sediments as a result of precipitation, sedimentation of insoluble substances and sorption by the loamy components of the sediments [Tarnawski 2012]. The quality of bottom sediments depends i.a. on the level of eutrophication of the water body, depth and on numerous factors related primarily to the lithological structure of the basin, soil type, terrain and management of the basin [Tarnawski 2012; Trojanowski and Antonowicz 2005]. In particular, agricultural areas are the areas, from which considerable amounts of substances dissolved in the process of water circulation are transferred [Krasowska and Banaszuk 2015]. In many cases, the knowledge of chemical composition of sediments is the better indicator of the quality of aquatic environment than the understanding of the more changeable water chemical composition. The knowledge of heavy metal content in sediments constitutes valuable material for the description of the sources, rate and ways of distribution of heavy metals in a water body, and it constitutes the basis for the determination of the possible repeated contamination of the waters of small water bodies [Sidoruk and Potasznik 
2013; Kazimierowicz and Kazimierowicz 2014; Szydłowski and Podlasińska 2016b].

The study aimed at the evaluation of the quality of bottom sediments and evaluation of potential threat to the aquatic environment.

\section{MATERIAL AND METHODS}

For the study, two ponds located near the village of Żelisławiec $\left(14^{\circ} 40^{\prime} 0.39^{\prime \prime} \mathrm{E}\right.$, $\left.53^{\circ} 16^{\prime} 10.64^{\prime \prime} \mathrm{N}\right)$ and Stare Czarnowo $\left(14^{\circ} 46^{\prime} 6.66^{\prime} \mathrm{E}, 53^{\circ} 16^{\prime} 4.18^{\prime} \mathrm{N}\right)$ were selected for the study, with the following water surface, respectively: 0.72 and 0.45 ha. The study objects are located in the agriculturally used basins, where wheat (Żelisławiec) and rape (Stare Czarnowo) were cultivated. The pond basins have considerably different sizes - 200 and 18.94 ha, respectively for Żelisławiec and Stare Czarnowo.

Sediment samples were collected from a boat with KC Denmark Kajak Sediment Core sampler, once in the autumn (2014), in two different points of the ponds in Żelisławiec (Z-1; Z-2) and in Stare Czarnowo (S-1; S-2), assuming, that these constituted the areas with the largest sedimentation of the finest sediments. The sediments were collected from the following layers: $0-5 \mathrm{~cm}, 5-20$ $\mathrm{cm}$ for the pond at Żelisławiec and additionally 20-30 from the pond at Stare Czarnowo.

The obtained soil material was prepared following the procedures used in soil science, and the analyzes were conducted in the particle fraction below $1 \mathrm{~mm}$. The total element content, i.e.: $\mathrm{Cd}, \mathrm{Co}, \mathrm{Cr}, \mathrm{Ni}, \mathrm{Pb}, \mathrm{Zn}$ were determined using atomic absorption spectrophotometer ASA ICE 3000 Thermo Scientific after a prior mineralization of the sediments in a mixture (5:1) of concentrated acids $\mathrm{HNO}_{3}(65 \%)$ and $\mathrm{HClO}_{4}(60 \%)$. $\mathrm{Hg}$ content was determined using AMA 254 analyzer. The precision of the used methods and analytical procedures was assessed on the basis of certified reference materials: sediments (Metals of sediment CRMO 15-050) and loamy sand (Loamy Sand 4 CRMO 36-050).

The obtained results were statistically elaborated using the Statistica 12.0 software. For the obtained results, the Shapiro-Wilk test of normality was used ( $\mathrm{p} \leq 0.05)$, which confirmed the normality of the result distributions.

Using the maximum values of heavy metal concentrations in the analyzed samples, an evaluation of the contamination of small water bodies was conducted using the following methods:
- aquatic sediment quality classification used by the Polish Geological Institute [Bojakowska 2001],

- index-Emgeoaccumulation (Igeo) [Müller 1981],

- the potential ecological risk index of individual element $\left[\mathrm{E}_{\mathrm{r}}\right]$ and the ecological potential index (PER), which constitutes the sum of all indexes of the ecological potential [Håkanson 1980] (Table 1).

For the evaluation, geochemical background was used, provided by the Polish Geological Institute [Bojakowska\&Sokołowska 1998].

In order to determine significance of the differences between the studied layers of sediments and the measurement points, Tukey's test was performed and the Pearson's linear correlation coefficient was calculated. All NIR and R values significant at the level of $\mathrm{p} \leq 0.05$ were expressed directly in the text.

\section{RESULTS AND DISCUSSION}

The obtained results of bottom sediment study in ponds of Stare Czarnowo and Żelisławiec are presented in Tables 2 and 3. Bottom sediments of the ponds were characterized by low $\mathrm{pH}$ values, which in $\mathrm{H}_{2} \mathrm{O}$ (active acidity) remained in the range from 4.86-5.47 (Żelisławiec) and 4.53-5.76 (Stare Czarnowo) (Table 2). The value of the C:N ratio depends on the chemical composition of the organic material deposited in the bottom sediments of water bodies. Low values occur, when the organic matter is rich in proteins (4 to 10 ratio), whereas high values of the $\mathrm{C}: \mathrm{N}$ ratio (above 20) characterize organic matter, the source of which are macrophytes and higher plants [Daniszewski 2012]. The conducted study demonstrated low variability of total carbon to total nitrogen ratio in the individual measurement points. This is reflected in the calculated values of

Table 1. Standards for classes Er and PER

\begin{tabular}{|c|c|c|c|}
\hline $\begin{array}{l}\text { The potential } \\
\text { ecological } \\
\text { risk index } \\
\text { individual } \\
\text { element }\left[E_{r}\right]\end{array}$ & $\begin{array}{l}\text { Ecological } \\
\text { risk index }\end{array}$ & $\begin{array}{l}\text { Indicator of } \\
\text { ecological } \\
\text { potential } \\
\text { (PER) }\end{array}$ & $\begin{array}{c}\text { Degrees of } \\
\text { potential } \\
\text { ecological } \\
\text { risk }\end{array}$ \\
\hline $\begin{array}{c}<40 \\
40-80 \\
80-160 \\
160-320 \\
>320\end{array}$ & $\begin{array}{c}\text { Low } \\
\text { Moderate } \\
\text { Higher } \\
\text { Much higher } \\
\text { Major }\end{array}$ & $\begin{array}{c}<150 \\
150-300 \\
300-600 \\
>600\end{array}$ & $\begin{array}{c}\text { Low quality } \\
\text { Moderate } \\
\text { Heavy } \\
\text { Major }\end{array}$ \\
\hline
\end{tabular}


Table 2. Basic chemical characteristics sediment samples examined small water reservoirs

\begin{tabular}{|c|c|r|r|r|r|}
\hline Points & $\begin{array}{c}\text { Layer } \\
{[\mathrm{cm}]}\end{array}$ & $\begin{array}{c}\mathrm{pH} \mathrm{w} \\
\mathrm{H}_{2} \mathrm{O}\end{array}$ & Losses & \multicolumn{1}{c|}{$\mathrm{C}$} & $\begin{array}{c}\text { Ratio } \\
\text { C:N }\end{array}$ \\
\hline \multicolumn{7}{|c|}{ Żelisławiec } \\
\hline \multirow{2}{*}{ Z-1 } & $0-5$ & 4.86 & 15.52 & 7.12 & 10.3 \\
\cline { 2 - 7 } & $5-20$ & 5.29 & 7.85 & 3.51 & 10.4 \\
\hline \multirow{3}{*}{ Z-2 } & $0-5$ & 5.01 & 15.26 & 7.04 & 10.4 \\
\cline { 2 - 7 } & $5-20$ & 5.47 & 8.21 & 3.00 & 10.3 \\
\hline \multirow{7}{|c|}{ Stare Czarnowo } \\
\hline \multirow{3}{*}{ S-1 } & $0-5$ & 5.76 & 27.83 & 13.31 & 11.6 \\
\cline { 2 - 7 } & $5-20$ & 5.33 & 14.72 & 7.36 & 14.2 \\
\cline { 2 - 7 } & $20-30$ & 5.14 & 20.78 & 10.07 & 11.6 \\
\hline \multirow{3}{*}{ S-2 } & $0-5$ & 5.21 & 30.11 & 13.62 & 13.3 \\
\cline { 2 - 7 } & $5-20$ & 4.81 & 22.79 & 10.87 & 12.7 \\
\cline { 2 - 7 } & $20-30$ & 4.53 & 8.61 & 3.90 & 14.3 \\
\hline
\end{tabular}

the $\mathrm{C}: \mathrm{N}$ ratio (Table 2). Sediments of the pond at Żelisławiec were characterized by narrow ranges, whereas in sediments of the Stare Czarnowo pond a wider range of $\mathrm{C}: \mathrm{N}$ ratio was found.

According to Januszkiewicz [1980], chemical transformations that occur in sediments cause considerably higher losses of $\mathrm{C}$ than $\mathrm{N}$, and on the basis of $\mathrm{C}: \mathrm{N}$ ratio it is possible to determine possible rate of sediment mineralization. Low C:N ratios demonstrate higher organic matter mineralization. The lower the ratio, the higher mineralization level [Trojanowski and Antonowicz 2005].

Higher total carbon was determined in the sediments of the pond in Stare Czarnowo (7.36$13.62 \%$ ), than in the Żelisławiec pond (3.00-
$7.12 \%$ ). The highest amount of organic matter was observed in the S-2 measurement point in the youngest layer $-30.11 \%$. In all studied points, the highest amount of carbon and organic matter was found in the top layer (W1). The calculated Pearson's linear correlation coefficient $(p<0.05)$ demonstrated highly statistically significant negative correlation $(-0.961)$ between $\mathrm{pH}$, and total carbon content.

The chemical analysis of separate layers of bottom sediments of ponds demonstrated higher accumulation of the examined heavy metals in the top layer $0-5 \mathrm{~cm}$ in Żelisławiec for cadmium, cobalt, chromium, copper, nickel, lead, zinc and mercury (Table 3 ). Their concentration in the separate layers decreased with the depth of the sediments (Table 3). The cause for the accumulation of higher amounts of the examined elements in the youngest layer $(0-5 \mathrm{~cm})$ is the increase of farming intensification [Szydłowski 2014; Brysiewicz et al. 2013]. On the other hand, higher concentrations of the examined elements in deeper layers of the sediment $(20-30 \mathrm{~cm})$ in the Stare Czarnowo pond (S-1) are linked to the higher supply of substances contaminating the waters in previous years. 82.42 times higher cadmium concentrations were determined for the youngest layer (the top layer) than the layer located below. On the other hand, in the sediments of the pond in Stare Czarnowo, the highest concentrations of the studied elements occurred in the deepest layer $(20-30 \mathrm{~cm})$. Only in the case of mercury, sedi-

Table 3. The content of heavy metals $\left[\mathrm{mg} \cdot \mathrm{kg}^{-1}\right]$ in the bottom sediments of small ponds

\begin{tabular}{|c|c|c|c|c|c|c|c|c|c|}
\hline Points & $\begin{array}{c}\text { Layer } \\
{[\mathrm{cm}]}\end{array}$ & $\mathrm{Cd}$ & Co & $\mathrm{Cr}$ & $\mathrm{Cu}$ & $\mathrm{Ni}$ & $\mathrm{Pb}$ & $\mathrm{Zn}$ & $\mathrm{Hg}$ \\
\hline \multicolumn{10}{|c|}{ Żelisławiec } \\
\hline \multirow{3}{*}{$Z-1$} & $0-5$ & 0.16 & 9.17 & 34.80 & 23.17 & 42.00 & 48.49 & 92.29 & 0.22 \\
\hline & $5-20$ & * & 6.70 & 28.98 & 15.93 & 35.84 & 35.00 & 61.42 & 0.11 \\
\hline & $x_{\text {sr }}$ & 0.08 & 7.94 & 31.89 & 19.55 & 38.92 & 41.74 & 76.85 & 0.16 \\
\hline \multirow{3}{*}{ Z-2 } & $0-5$ & * & 10.06 & 40.30 & 26.52 & 50.08 & 57.70 & 96.01 & 0.21 \\
\hline & $5-20$ & * & 7.86 & 35.73 & 18.01 & 43.59 & 40.35 & 69.77 & 0.12 \\
\hline & $x_{\text {śr }}$ & * & 8.96 & 38.02 & 22.27 & 46.84 & 49.03 & 82.89 & 0.17 \\
\hline \multicolumn{10}{|c|}{ Stare Czarnowo } \\
\hline \multirow{4}{*}{ S-1 } & $0-5$ & 0.45 & 6.87 & 26.76 & 15.89 & 30.02 & 46.88 & 92.49 & 0.2 \\
\hline & $5-20$ & 0.25 & 3.68 & 19.02 & 8.07 & 15.82 & 20.12 & 40.35 & 0.25 \\
\hline & $20-30$ & 0.67 & 8.80 & 39.55 & 22.26 & 47.38 & 53.84 & 107.88 & 0.16 \\
\hline & $x_{s r}$ & 0.55 & 7.44 & 31.50 & 17.51 & 36.17 & 49.79 & 86.85 & 0.20 \\
\hline \multirow{4}{*}{ S-2 } & $0-5$ & 0.73 & 7.03 & 28.53 & 15.42 & 27.11 & 42.16 & 76.69 & 0.12 \\
\hline & $5-20$ & 0.51 & 6.66 & 28.19 & 14.37 & 31.13 & 48.64 & 60.16 & 0.24 \\
\hline & $20-30$ & 0.24 & 2.92 & 11.74 & 5.90 & 11.89 & 14.08 & 24.64 & 0.10 \\
\hline & $x_{\text {sr }}$ & 0.40 & 4.55 & 19.76 & 9.79 & 18.28 & 25.45 & 47.23 & 0.16 \\
\hline
\end{tabular}

Explanation: * - below the limit of quantification 
ments of the pond contained higher concentrations in the top layer $(0-5 \mathrm{~cm})$.

Mean cobalt, chromium, copper, nickel and lead concentrations reported for both ponds and cadmium in the Stare Czarnowo pond (S-1 point) were higher than the biochemical background provided by Bojakowska and Sokołowska [1998] for these metals in aquatic sediments, which are for cadmium $<0.5$; cobalt 2 ; chromium 5 ; copper 6 ; mercury $<0.05$; nickel 5 ; lead 10 and zinc 48 $\mathrm{mg} \cdot \mathrm{kg}^{-1}$. The exceeded natural values may stem from the presence of agricultural lands in the direct vicinity of the analyzed ponds. The exceeded natural values demonstrate the negative influence of the agricultural terrains adjacent to the ponds, where the main source of the analyzed heavy metals are surface runoffs, use of plant protection chemicals and the use of organic fertilizers for soil fertilization [Kazimierowicz and Kazimierowicz 2014; Sidoruk and Potasznik 2013].

Cadmium concentrations in the studied bottom sediments ranged from $<0.005 \mathrm{mg}$ (limit of quantification) to $0.73 \mathrm{mg} \cdot \mathrm{kg}^{-1}$ and these were lower than determined by Szydłowski and Podlasińska [2016a] in bottom sediments of ponds, sediments of the Biebrza river basin [Kazimierowicz and Kazimierowicz 2014], bottom sediments of the Szczecin agglomeration water bodies [Sammel 2015] and concentrations in the bottom sediments of the Besko reservoir on the Wisłokriver [Madeyski and Tarnawski 2007]. The highest cadmium concentration of $0.73 \mathrm{mg} \cdot \mathrm{kg}^{-1}$ is respectively two and eight times lower than the highest concentrations of the study of Szydłowski and Podlasińska [2016a] and Marek [1989].

In the case of cobalt, its concentration was from $2.92 \mathrm{mg}$ to $10.06 \mathrm{mg} \mathrm{Co} \cdot \mathrm{kg}^{-1}$ and was similar to the results obtained by Sammel [2015] for thesediements in pond no. $2\left(4.30-8.72 \mathrm{mg} \cdot \mathrm{kg}^{-1}\right)$, and was lower than the sediment concentrations of pond no. 1 (2.81-16.92 $\left.\mathrm{mg} \cdot \mathrm{kg}^{-1}\right)$ located in the Szczecin agglomeration and higher than the concentration range of the lakes of the Kashubian Lake District (1-8 $\mathrm{mg} \cdot \mathrm{kg}^{-1}$ ) [Bojakowska and Sokołowska 1998].

Considering the mean chromium concentration in bottom sediments of both analyzed ponds, a two-fold higher concentration of the metal in the Żelisławiec pond was determined $\left(38.02 \mathrm{mg} \cdot \mathrm{kg}^{-1}\right)$ than in the Stare Czarnowo pond $\left(19.76 \mathrm{mg} \cdot \mathrm{kg}^{-1}\right)$. Lower mean chromium concentrations were determined by Szydłowski and Podlasińska [2016a] for the bottom sediments of the pond located in a village park $\left(13.81 \mathrm{mg} \cdot \mathrm{kg}^{-1}\right)$ and sediments in the Biebrza river basin and its three affluents $(9.67$ $\mathrm{mg} \cdot \mathrm{kg}^{-1}$ ) [Kazimierowicz and Kazimierowicz 2014]. On the other hand, the highest chromium concentration in the Żelisławiec pond was respectively two times lower than in the Madeyski and Tarnawski study [2007] conducted in the Besko reservoir and similar to the highest concentration in the sediments of the Rzeszów reservoir, which is $31.56 \mathrm{mg} \cdot \mathrm{kg}^{-1}$ [Baran and Tarnawski 2012].

In the bottom sediments of the ponds, copper occurred from trace amounts to $26.52 \mathrm{mg} \cdot \mathrm{kg}^{-1}$. The maximum value is three times higher than in the highest determined concentration of copper for the Biebrza river sediments [Kazimierowicz and Kazimierowicz 2014] and 1.5 times higher than in the Rzeszów reservoir sediments [Baran and Tarnawski 2012). On the other hand, considerably higher copper concentrations than in the present own study occurred in the sediments of the water bodies of the Szczecin agglomeration, amounting to $994.1 \mathrm{mg} \cdot \mathrm{kg}^{-1}$ (38-fold higher concentration) [Sammel 2015] and in the Zesławice reservoir, where the highest copper concentration was $50.0 \mathrm{mg} \cdot \mathrm{kg}^{-1}$ and was two-fold higher [Baran and Tarnawski 2013]. Similar copper concentrations were observed in bottom sediments of the Besko reservoir [Madeyski and Tarnawski 2007].

Nickel concentrations in the sediments were from $11.89 \mathrm{mg}$ to $50.08 \mathrm{mg} \cdot \mathrm{kg}^{-1}$ and were similar to the nickel values obtained in the sediments of the Szczecin agglomeration [Sammel 2015]. The nickel range in the own study was higher than in the Besko reservoir sediments (25.30$37.50 \mathrm{mg} \cdot \mathrm{kg}^{-1}$ ) [Madeyski and Tarnawski 2007], Zesławice reservoir $\left(10.4-16.6 \mathrm{mg} \cdot \mathrm{kg}^{-1}\right)$ [Baran and Tarnawski 2013] and the Biebrza river basin and three its affluents $\left(0.6-22.9 \mathrm{mg} \cdot \mathrm{kg}^{-1}\right)$ [Kazimierowicz and Kazimierowicz 2014]. The maximum nickel concentrations occurred in the city canal in Wrocław at the ZNTK Wrocław measuring point $\left(100 \mathrm{mg} \cdot \mathrm{kg}^{-1}\right)$, Wrobet $\left(86 \mathrm{mg} \cdot \mathrm{kg}^{-1}\right)$, Browar Piastowski $\left(88 \mathrm{mg} \cdot \mathrm{kg}^{-1}\right.$ ) Warsaw Bridge $\left(112 \mathrm{mg} \cdot \mathrm{kg}^{-1}\right)$ [Dziadowska and Noga 2008].

Lead in the sediments of the studied ponds was determined in the range from 14.08-57.71 $\mathrm{mg} \cdot \mathrm{kg}^{-3}$, and mean concentration was from 25.45 to $49.80 \mathrm{mg} \cdot \mathrm{kg}^{-1}$ in individual test points. The highest mean concentration in the own study was higher than determined for the sediments of the reservoir no. $2\left(35.42 \mathrm{mg} \cdot \mathrm{kg}^{-1}\right)$ and almost four times lower than the mean lead concentration in the sediments of the reservoir no. 1 in the Szcze- 
cin agglomeration [Sammel 2015]. Similar maximum lead concentrations were determined for the sediments in the Zesławice reservoir (56.49 $\left.\mathrm{mg} \cdot \mathrm{kg}^{-1}\right)$. On the other hand, higher maximum concentrations occurred in the study of the city canal in Wrocław, at the Browar Piastowski measurement point $\left(321.86 \mathrm{mg} \cdot \mathrm{kg}^{-1}\right)$ and in the pond no. 1 located in the Szczecin agglomeration (206.29 $\mathrm{mg} \cdot \mathrm{kg}^{-1}$ ) [Sammel 2015]. The bottom sediments of the Besko reservoir [Madeyski and Tarnawski 2007] were characterized by lower and considerably narrower range from 16.00 to $17.90 \mathrm{mg} \cdot \mathrm{kg}^{-1}$.

Zinc in the sediments of the studied ponds occurs in concentrations from 24.64 to 107.89 $\mathrm{mg} \cdot \mathrm{kg}^{-1}$, and its mean concentrations in the individual points amounted from 47.23 to 86.85 $\mathrm{mg} \cdot \mathrm{kg}^{-1}$ and were similar to the zinc contents in aquatic sediments of the whole Poland [Lis and Pasieczna 1955]. The highest concentration was determined in the Stare Czarnowo pond (107.88 $\left.\mathrm{mg} \cdot \mathrm{kg}^{-1}\right)$. At the same time, the similar zinc concentration occurred in the sediments of the Rzeszów reservoir and was $105.43 \mathrm{mg} \cdot \mathrm{kg}^{-1}$ [Baran and Tarnawski 2012] and in the sediments of the Zesławice reservoir, where it was $115.10 \mathrm{mg} \cdot \mathrm{kg}^{-1}$ [Madeyski and Tarnawski 2007]. In the study of Kazimierowicz and Kazimierowicz [2014] the maximum concentration was two times higher, whereas in the study of Sammel [2015] it was six times higher.

In the analyzed sediments, mercury occurred in the range from 0.100 to $0.249 \mathrm{mg} \cdot \mathrm{kg}^{-1}$. Concentrations of this metal in the own study were lower than determined in the study of Dziadowska and Noga [2008] and Rzętała [2012]. The highest mercury concentration was respectively fourteen and thirteen times lower than in the work of the above authors. However, these concentrations were similar to the concentrations obtained in the work of Bojakowska and Sokołowska [1996] from $<0.05$ to $0.52 \mathrm{mg} \cdot \mathrm{kg}^{-1}$.

The evaluation of small water bodies contamination was conducted using maximum concentrations of heavy metals in the analyzed samples (Table 4). Following the PIG classification [Bojakowska 2001], the sediment samples collected from the examined ponds are classified between the first and second class for pond in Żelisławiec, and from first to fifth class for pond sediments in Stare Czarnowo. In the studied ponds, the bottom sediments are primarily classified as moderately polluted (II class), i.e. those, which can be assumed as sediments in which the influence of harmful substances on aquatic organisms is rare. The highest nickel concentration obtained in the own study in the sediment sample from the pond in Żelisławiec classifies the sediment as average contaminated, for which the influence of harmful substances on aquatic organisms is often observed (Table 4). The sediments classified as uncontaminated (I class) and moderately polluted (II class) can be freely managed in the terrestrial as well as aquatic environment, whereas III class sediments can be relocated in the water in designated areas, and managed to a limited extent on the land, since concentrations of certain metals may limit its use not only for industrial cultivations, but also exclude it from agricultural use [Bojakowska and Sokołowska 2001].

Following the Igeo classification, the analyzed sediments remain between the uncontaminated class (I class) and extremely polluted class (VI class). In both ponds, the $\mathrm{I}_{\text {geo }}$ values characterize metals, of which elevated amounts in the environment are related to the human activity-zinc and lead (Table 4).

Due to the obtained values of the potential ecological risk index of individual element $\left[\mathrm{E}_{\mathrm{r}}\right]$ in the examined period, the following series can be arranged for the sediments in the pond at Żelisławiec $\mathrm{Ni}>\mathrm{Pb}>\mathrm{Cu}>\mathrm{Cr}>\mathrm{Cd}>\mathrm{Zn}$, and for the pond at Stare Czarnowo-Ni $>\mathrm{Cd}>\mathrm{Pb}>\mathrm{Cu}>\mathrm{Cr}>\mathrm{Zn}$ (Table 5). By evaluating the highest concentra-

Table 4. Classification of contamination of sediments surveyed small ponds by selected evaluation methods

\begin{tabular}{|c|c|c|c|c|}
\hline Ponds & Elements & $\begin{array}{c}\text { The maximum } \\
\text { concentration } \\
{\left[\mathrm{mg} \cdot \mathrm{kg}^{-1}\right]}\end{array}$ & PIG* & $I_{\text {geo/llass }}$ ** \\
\hline \multirow{8}{*}{ Żelisławiec } & $\mathrm{Cd}$ & 0.16 & I & -4.19 \\
\hline & Co & 10.06 & II & 3.75 \\
\hline & $\mathrm{Cr}$ & 40.30 & II & 7.07 \\
\hline & $\mathrm{Cu}$ & 26.52 & II & 6.73 \\
\hline & $\mathrm{Ni}$ & 50.08 & III & 7.38 \\
\hline & $\mathrm{Pb}$ & 57.70 & II & 8.59 \\
\hline & $\mathrm{Hg}$ & 0.22 & II & -7.12 \\
\hline & $\mathrm{Zn}$ & 96.01 & 1 & 11.59 \\
\hline \multirow{8}{*}{$\begin{array}{c}\text { Stare } \\
\text { Czarnowo }\end{array}$} & $\mathrm{Cd}$ & 0.73 & 1 & -2.04 \\
\hline & Co & 8.80 & I & 3.55 \\
\hline & $\mathrm{Cr}$ & 39.55 & II & 7.04 \\
\hline & $\mathrm{Cu}$ & 22.26 & II & 6.48 \\
\hline & $\mathrm{Ni}$ & 47.38 & II & 7.3 \\
\hline & $\mathrm{Pb}$ & 53.84 & II & 8.49 \\
\hline & $\mathrm{Hg}$ & 0.25 & II & -6.91 \\
\hline & $\mathrm{Zn}$ & 107.9 & 1 & 11.75 \\
\hline
\end{tabular}


tions of heavy metals in the sediments, determined in own study, the analyzed sediment samples should be classified as sediments with moderate contamination risk index (Table 5). The level of the potential ecological risk (PER) for the sediments in Żelisławiec classifies them as sediments with low quality of the potential ecological risk, whereas for the sediments in Stare Czarnowo, as sediments with moderate level of the potential ecological risk (Table 5).

The statistically significant differences between the analyzed layers were observed in Żelisławiec for manganese (0.009), zinc (0.250) and mercury (0.010), and a statistically significant difference between the examined points was determined for potassium only in the sediments from the pond at Żelisławiec.

\section{CONCLUSIONS}

1. The highest concentration of the studied heavy metals was found in the top layer $0-5 \mathrm{~cm}$ in Żelisławiec for cadmium, cobalt, chromium, copper, nickel, lead, zinc and mercury.

2. The concentration of the studied heavy metals in individual layers decreased with the depth of the sediments.

3. In both ponds, the highest $I_{\text {geo }}$ values characterize the metals, of which elevated amounts in the environment are related to the human activity-zinc and lead.

4. Pool sediments in Żelisławiec are classified as low quality of the potential ecological risk, whereas the sediments from the pond at Stare Czarnowo-moderate.

\section{REFERENCES}

1. Baran A., Tarnawski M. 2012. The content of heavy metals in water extracts prepared from the bottom sediments reservoir Rzeszowski. Proceedings of ECOpole, 6(2), 671-675.

2. Baran A., Tarnawski M. 2013. The content of heavy metals and toxicity of bottom sediments in the reservoir Zeslawice. Proceedings of ECOpole, $7(2), 531-537$.

3. Bojakowska I. 2001. The criteria for the assessment of sediment contamination of water. Przegląd Geologiczny, 49(3), 213-218.

4. Bojakowska I., Sokołowska G. 1996. Heavy metals in the sediments of lakes Pojezierza Kaszubskiego. Przegląd Geologiczny, 44(9), 920-923.
Table 5. The values of the ecological risk index and the ratio of ecological potential for heavy metal content in the tested types of ponds

\begin{tabular}{|c|c|c|c|c|c|c|}
\hline \multirow{2}{*}{ Class } & \multicolumn{7}{|c|}{ Elements } \\
\cline { 2 - 7 } & $\mathrm{Cd}$ & $\mathrm{Cr}$ & $\mathrm{Cu}$ & $\mathrm{Ni}$ & $\mathrm{Pb}$ & $\mathrm{Zn}$ \\
\hline \multicolumn{7}{|c|}{ Żelisławiec } \\
\hline $\mathrm{E}_{\mathrm{r}}$ & 9.83 & 16.12 & 22.10 & 60.09 & 28.85 & 2.00 \\
\hline PER & \multicolumn{7}{|c|}{ Stare Czarnowo } \\
\hline \multicolumn{7}{|c|}{164.10} \\
\hline $\mathrm{E}_{\mathrm{r}}$ & 43.72 & 15.82 & 18.55 & 56.85 & 26.92 & 2.25 \\
\hline PER & \multicolumn{7}{|c|}{} \\
\hline
\end{tabular}

5. Bojakowska I., Sokołowska G. 1998. Geochemical class purity water sediments. Przegląd Geologiczny, 46(1), 49-54.

6. Borówka R.K. 2007. Geochemical studies lacustrine sediments of the temperate zone. Studia Limnologica et Telmatologica, 33-42.

7. Brysiewicz A., Wesołowski P., Rawicki K. 2013. Comparison of concentrations of chemical components in the water with field-pond and groundwater from adjacent farmland. Woda Środowisko Obszary Wiejskie, 13(2), 17-31.

8. Daniszewski P. 2012. The values of C: $\mathrm{N}$ ratio for the bottom sediments of Lake Barlinek (spring, summer and autumn of 2008.). International Letters of Chemistry, Physics and Astronomy. 2, 46-52.

9. Dziadowska K., Noga L. 2008. Rating geotechnical conditions and quality standards of sediments for the modernization of the canal city of Wrocław. Górnictwo I Geoinżynieria, 2, 99-104.

10. HåkansonL. 1980. An ecological risk index for aquatic pollution control. A sedimentological approach. Water Research, 14, 975-1001.

11. Januszkiewicz T. 1980. Chemical characteristics of recent sediments of Lake Wierzysko. Polish Archives of Hydrobiology, 26, 475-493.

12. Kazimierowicz Z., Kazimierowicz J. 2014. The study of heavy metals in the river basin of the Biebrza and its three tributaries. Inżynieria Ekologiczna, 40, 25-32.

13. Krasowska M., Banaszuk P. 2015. Migration of nutrients in agricultural catchment. Inżynieria Ekologiczna, 43, 35-41.

14. Lis J., Pasieczna A. 1995. Geochemical Atlas of Polish in scale 1: 2500 000. Państwowy Instytut Geologiczny. Warszawa.

15. Madeyski M., Tarnawski M. 2007. Preliminary assessment of the quantity and quality of bottom sediments separate part of the water reservoir on the river Besko Wisłok. Infrastructure and ecology of rural areas, 4(1), 101-110.

16. Marek J. 1989. Heavy metals in bottom sediments 
of the river basin Barycz. Ochrona Środowiska, 2(39), 31-34.

17. Müller G. 1981. Die Schwermetallbelastung der Sedimenten des Neckers und Seiner Nebenflusse. Chemiker - Zeitung, 6: 157-164.

18. Rzętała A.M. 2012. Mercury in the bottom sediments of water bodies in the region of the Upper Silesia (Southern Poland). Acta Geographica Silesiana, 2, 77-81.

19. Sammel A. 2015. The chemical composition of bottom sediments of water bodies Syrenie Ponds Szczecin agglomeration and the possibility of their use. Uniwersytet Zielonogórski, Zeszyty naukowe 157, 53-60.

20. Sidoruk M.,Potasznik A. 2013. Assessment of pollution by lead, zinc, chromium and bottom sediments of the lake Sunia. Proceedings of ECOpole,
7(2), 713-720. (in Polish)

21. Szydłowski K. 2014. Concentrations of nutrients in surface waters of small water reservoirs. Dokonania Młodych naukowców, 5, 156-160.

22. Szydłowski K., Podlasińska J. 2016a. Characteristics of bottom sediment ponds. Inżynieria Ekologiczna, 47, 40-46.

23. Szydłowski K., Podlasińska J. 2016b. The concentration of some heavy metals in sediments watercourse. Infrastructure and ecology of rural areas, 1. 59-71

24. Tarnawski M. 2012. The condition of heavy metals in bottom sediments of the reservoir Zesławice. Inżynieria Ekologiczna, 31, 119-127.

25. Trojanowski J., Antonowicz A. 2005. The chemical properties of bottom sediments of the lake Dołgie Wielkie. Słupskie Prace Biologiczne, 2, 123-133. 